UDC 378:011.3-051:7

DOI: $10.31470 / 2415-3729-2019-9-115-127$

\title{
Methodological Basis of the Ornamental Study in the Process of Professional Training of Art Teachers
}

\section{Tetiana Nosachenko \\ Doctor of Philosophy in Pedagogy (Ph.D),} Associate Professor of the Department of Artistic Disciplines and Teaching Methods

Pereiaslav-Khmelnytskyi Hryhorii Skovoroda State Pedagogical University, $\square$ 30, Sukhomlynskyi Str., Pereiaslav-Khmelnytskyi, Kyiv Region, Ukraine, 08401 E-mail: tanyanosachenko@ukr.net ORCIDiD: 0000-0003-3625-0055

Date of receipt of the article: December 03, 2018 Article accepted for publication: February 22, 2019

\section{Методологічні основи вивчення орнаменту у процесі професійної підготовки вчителів мистецтва}

\section{Тетяна Борисівна Носаченко}

кандидат педагогічних наук, доцент кафедри мистецьких дисциплін та методики викладання ДВНЗ «Переяслав-Хмельницький державний педагогічний університет імені Григорія Сковороди», $\bowtie$ вул. Сухомлинського, 30, м. Переяслав-Хмельницький, Київська обл., Україна, 08401

Дата надходження статті: 03 грудня 2018 p. Стаття прийнята до друку: 22 лютого 2019 р.

\section{Abstract}

The article reveals the content and significance of decorative and applied arts in the system of art-pedagogical 
education, reveals the methodical aspects of studying the ornament, as a means of forming the professional skill of future fine arts teachers.

The decorative-applied art is characterized in the article by the unity of the artistic structure, the presence of various activities and acts as an effective means of aesthetic education of the students' personalities, the formation of their artistic taste. The author of the article defines that involving students in various types of artistic and applied arts, based on a folk art, is one of the main conditions for a full-fledged aesthetic education and the development of their artistic and creative abilities.

It is also noted in the study that one of the main «tools» for creating an image of decorative arts is an ornament. The article shows the urgency and necessity of improving the technique of studying the ornament in the process of professional training of students of the artistic profile. The ornament is considered by the researcher as a means of the development of students' professional skills, spatial thinking, formation of author's style and creative personality.

The author of the article believes that, studying the symbolic content of the ornaments, students become acquainted with their simplest archaic motifs, those are: a line, a circle, a cross, a rhombus, a square, a point, that is essential for forming an understanding of the integrity of an artistic work, aims to form a sense of the compositional laws of shaping and decorating and develop on this basis their artistic and creative abilities. Moreover, the researcher notes that the sense of rhythm, the harmony of color, the balance of form and color, which students receive during the study of ornament, allow them to creatively realize themselves in various types of paintings and decorative compositions, raise the level of artistic and creative abilities in general.

The author of the article gives the conclusion that an assimilation of techniques of the image of the ornament in various techniques, studying the types of ornamental art, laws and rules of ornamentation contribute to raising the level of artistic and creative abilities of students provided the introduction of modern scientifically sound teaching methods. 
Key words: teacher of fine arts, student, arts and crafts, folk art, vocational training, professional education, ornament, symbols, professional skills, ornamental composition.

\section{References}

1. Antonovych, Ye. \& Zakharchuk-Chuhai, R. (2012). Ukrainske dekoratyvne mystetstvo: navch. posib. [Ukrainian Decorative Arts: teach. manual]. Kyiv : Znannia [in Ukrainian].

2. Lozko, H.S. (2004). Etnolohiia Ukrainy: Filosofskoteoretychnyi ta etnorelihiieznavchyi aspekt [Ethnology of Ukraine: The philosophical-theoretical and the ethnoreligious aspects]. Kyiv : ArtEk [in Ukrainian].

3. Popova, B.V., Ihnatova, V. O. \& Stepyko, M. T. (1998). Fenomen natsii: osnovy zhyttiediialnosti [The phenomenon of the nation: the basis of life]. Kyiv : Znannia, NAN Ukrainy, Instytut filosofii [in Ukrainian].

4. Driapika, V.I. \&Savchenko, N.S. (2002). Rozkryvaiuchy estetychni tsinnosti ukrainskoho narodnoho mystetstva: Knyha dlia vchytelia [Exposing the aesthetic values of the Ukrainian folk art: A book for a teacher]. Kirovohrad : TOV «Imeks LTD» [in Ukrainian].

\section{Вступ}

Орієнтуючись на світові й державні стандарти в галузі освіти, враховуючи нагальні потреби сучасної української національної школи, викладач образотворчого мистецтва повинен мати високий рівень професійної підготовки, широку ерудицію і загальну культуру, розвинену національну самосвідомість, чітко визначену громадянську і моральну позицію, здатність до самопізнання та постійного самовдосконалення.

Формування високого рівня професійної компетентності майбутніх педагогів-художників сьогодні розглядається як основний напрямок мистецької освіти. Саме тому освітній процес художньо-педагогічних факультетів спрямовується на формування у студентів авторського 
індивідуального стилю, що проявляється в самостійній художньо-педагогічній творчості.

Значне місце в процесі художньо-педагогічної освіти майбутніх фахівців мистецтва займає досконале вивчення декоративно-прикладного мистецтва, що уособлює поєднання художнього стилю, семантики, структури та видових категорій i здійснює ефективний вплив на формування естетичного й морального компоненту професійної компетентності особистості, формування ii художньо-естетичних цінностей.

Вивчення народного мистецтва, впровадження в освітні програми декоративно-прикладної творчості, як змістового компоненту, забезпечує реалізацію завдань естетичного розвитку, формування художньо-творчої компетентності майбутніх учителів образотворчого мистецтва.

Зміст професійної художньо-педагогічної підготовки майбутніх учителів потребує спрямування освітнього процесу на більш ретельне вивчення культурної спадщини свого народу, що в свою чергу забезпечить розуміння ними значимості інтелектуальності, освіченості й інтелігентності.

На думку науковців, народному мистецтву властива особлива символічно-образна мова, яка допомагає відтворити етнічні традиції культури будь-якого народу, його звичаї, побут, природу, духовну спадщину, розкрити «споконвічні цінності духовного життя народу» (Антонович, 2012: 30).

Декоративно-прикладна творчість допомагає майбутньому вчителеві розкрити тенденції етнографії мистецтва регіону, пізнати вітчизняну культурну спадщину, залучити до першоджерел національної культури з метою усвідомлення багатства й глибини історичної пам'яті українського народу.

Відродження й розвиток стародавніх видів і жанрів народного декоративного мистецтва та художніх промислів, які впродовж віків репрезентували національну художню культуру, зокрема, гончарства, ткацтва, килимарства, ковальства, лозоплетіння, малярства, дерев'яної скульптури, декоративного розпису, виготовлення виробів зі шкіри, 
кістки, кореня сосни, соломи, народного вбрання, - $\epsilon$ актуальною потребою сьогодення.

Виховний аспект мистецтва досліджують у своїх роботах М. Бахтін, Д. Богоявленська, В. Бутенко, Л. Виготський, I. Зазюн, Ю. Летман, М. Каган, Б. Неменський, О. Рудницька, О. Семашко, В. Сухомлинський.

Питання культурологічного підходу до проблем формування особистості майбутнього педагога досліджувалися в наукових працях А. Бойко, В. Ванслова, М. Гончаренко, Л. Кондрашової, П. Крилової, М. Лещенко, Л. Луганської, О. Шевнюк, Г. Шевченко.

Дослідженнями виховного потенціалу народного мистецтва займалися В. Дряпіка, М. Закович, Г. Лозко, Л. Михайлюк, Л. Степико, Н. Савченко.

Народне декоративно-прикладне мистецтво, як компонент культури української нації, характеризується надзвичайною різноманітністю видів та стилів, що $\epsilon$ відображенням традицій давніх культур. Символічнообразний зміст творів декоративно-прикладного мистецтва $€$ джерелом формування ціннісного світогляду студентів, сприйняття традицій, норм поведінки й культури свого народу. У процесі вивчення декоративно-прикладного мистецтва студенти усвідомлюють зміст і мову етносу, вчаться «вільно володіти й користуватися мовою народного мистецтва» (Лозко, 2004: 59-60).

Під час вивчення основних орнаментальних символів, на основі аналізу декоративних розписів, майбутні вчителі образотворчого мистецтва виокремлюють крапку, лінію, коло, квадрат, ром, хрест й роблять висновок, що вони є основними й найпростішими елементи архаїчних мотивів. На основі найпростіших орнаментальних символів та їх декоративного поєднання створюються орнаментальні композиції практичних завдань, що має важливе значення для формування розуміння у студентів цілісності художнього твору, відчуття композиційних законів побудови форми та декору й розвитку їх художньо-творчого потенціалу, як компоненту професійної компетентності майбутнього вчителя мистецтва. 
Велика увага педагогічної науки до формування фахової компетентності майбутніх педагогів мистецького профілю у процесі професійної підготовки доводить актуальність піднятої проблеми й вимагає активного пошуку нових технологій підвищення якості цього процесу засобами орнаментального мистецтва.

У наукових працях А. Бакушинского, В. Воронової, Т. Соколової досліджуються історія розвитку орнаменту. Вчені С. Антонович, В. Василенко, М. Кириченко, М. Некрасова, М. Селівачов, К. Юнг вивчали семантику й специфіку орнаментального мистецтва. Вивчення природи й особливостей орнаментального мистецтва спрямоване на забезпечення студентів знаннями й уміннями з художнього декору, сприяє оволодінню прийомами створення декоративного оздоблення різних форм 3 урахуванням сучасних художніх технік, матеріалів i естетичного сприйняття.

Актуальні завдання сучасної мистецької освіти, зокрема вивчення декоративно-прикладного мистецтва, висвітлено у працях Г. Васяновича, І. Зязюна, М. Лещенко, Л. Масол, Н. Миропольської, О. Отич, Г. Падалки, В. Рибалки, О. Рудницької, Г. Сотська, О. Шевнюк, О. Щолокової, В. Шульгіної. Вчені доводять, що у процесі вивчення орнаменту, створення декоративних композицій та виконання розписів, студенти мають змогу творчо реалізовувати себе на основі відчуття гармонії кольору й ритму, розуміння рівноваги кольору і форми, що дозволяє підвищити рівень спеціальних компетенцій та професійної компетентності в цілому.

Аналіз наукової та педагогічної літератури дозволяє стверджувати, що питання професійного розвитку студентів мистецького профілю засобами орнаменту у системі вищої професійної освіти залишається не достатньо вивченим. У дослідженнях науковців і педагогів-методистів відсутня апробована модель теоретично обгрунтованих педагогічних умов формування професійної компетентності педагогів мистецтва засобами орнаменту, не достатньо розроблена дана проблема в теорії і практиці професійної художньопедагогічної освіти. 
Метою статті є дослідження методичних аспектів впровадження в процес фахової художньо-педагогічної освіти сучасних технологій вивчення орнаменту, як засобу формування професійної компетентності у майбутніх учителів-художників.

\section{Матеріал і методи досліджень}

У статті використано теоретичні (аналіз та узагальнення) та емпіричні (спостереження, порівняння) методи дослідження.

\section{Результати та їх обговорення}

Народне мистецтво відображає навколишній світ за допомогою стародавньої, традиційної системи символів (В. Василенко, М. Некрасова, Н. Сакуліна Т. Шпикалова), що століттями набували характерних рис на основі орнаментального мистецтва, його колориту, композиційного ладу, елементів.

Орнамент $є$ одним 3 основних «інструментів» створення образу в декоративно-прикладному мистецтві. Виникнення та розвиток орнаментального мистецтва відображає інтеграцію пізнавального, соціального та естетичного компоненту життя людини різних епох.

Студенти, у ході дослідження змісту орнаментальних мотивів, 3'ясовують, що ромб $\epsilon$ одним 3 основних найдревніших символів. Він вживався для зображення мамонта, що символізував - благо, могутність, багатство. Наші пращури використовували ромб у орнаментальних зображеннях як символ, що приносить добробут та захищає від біди. Використання ромбу в орнаменті застосовувалося ще 3 часів палеоліту і зустрічається в орнаментальному мистецтві усіх народів світу. Інтерпретований у подальшому, цей мотив використовувався у європейських культурах землеробів, як символ родючості. Пізніше цей символ доповнювався гачками й крапками і втілював ідею багатої родючості землі.

Вчені зазначають, що стилізованість художнього образу орнаменту виражається через ритмічне чергування ліній, крапок, мотивів, що відтворюють рух і форми природи. Так, на основі узагальнення абстрактних форм створюється 
геометричний орнамент (Ю. Герчук, Т. Комарова, Н. Романова та ін.). Геометричний орнамент в повній мірі представлений в традиційній вишивці й ткацтві (Н. Климова, T. Комарова, М. Некрасова, Т. Семенова, В. Фаворський та iн.). Походження геометричного орнаменту пов'язане 3 технікою переплетення ниток в тканині. Тому в геометричній орнаментиці переважають ромби, квадрати, хрести, горизонтальні й хвилясті лінії, що володіють образним змістом й відображають уявлення давніх людей про космос, родючість землі (3. Богатєєва, Ю. Герчук, В. Фаворський та ін.).

Вивчаючи та аналізуючи особливості орнаментів народів світу, студенти прослідковують історію формування людських цінностей i усвідомлюють взаємозв'язок між наукою і творчістю, релігією і філософією, творчістю і естетикою. Такі підходи до вивчення орнаменту, його історії, стильових та семантичних особливостей дозволяють більш глибоко зрозуміти закономірності розвитку світової культури, зокрема мистецтва орнаменту (Феномен нації..., 1998: 108).

Розуміння знаково-символічної мови українського орнаменту, його колорит, технологічні прийоми має важливе значення для формування у студентів сприйняття цілісності орнаментальній композиції, розвитку композиційної компетентності, відчуття взаємозалежності форми та декору.

Твори народного декоративно-прикладного мистецтва $\epsilon$ відображенням «національного фольклору, традицій i цінностей» (Дряпіка, 2002: 46). Тому, у процесі вивчення українських орнаментів доцільно використовувати поетичні твори й народну музику, вивчати художні особливості творів регіональних та всесвітньо відомих майстрів: Катерини Білокур, Марії Приймаченко, Марії Буряк. Так, аналізуючи наївний живопис Івана Приходька з Київщини, у творах якого відображається фольклор та традиції українського народу, студенти прослідковують їх зв'язок з народною мудрістю, світосприйманням і національною свідомістю.

Орнаменту, як одному з видів декоративного мистецтва, властивим є узагальненість форми, ритмічність повторення елементів, колористика, що додають завершеності художньому твору. 
Вивчення орнаменту в курсі «Декоративно-прикладне мистецтво» ставить за мету вирішення таких завдань:

- ознайомлення з історичними аспектами виникнення й розвитку орнаменту;

- вивчення стилів та мови видів декоративноприкладного мистецтва;

- усвідомлення основних законів й принципів композиційної побудови орнаментального декору;

- формування вміння використовувати символіку орнаменту як засобу художньої виразності;

- вироблення навичок цілеспрямованого й послідовного виконання орнаментальної композиції;

- забезпечення розуміння схематичної побудови орнаменту;

- активізація інтелектуальних і творчих здібностей студентів;

- формування емоційно-ціннісного ставлення студентів до мистецтва і культури свого народу.

Окреслені завдання реалізуються в процесі опрацювання художнього досвіду майстрів декоративної композиції Київщини: П. Власенко, К. Білокур, М. Буряк, М. Приймаченко, Г. Собачко-Шостак та ін. Аналізуючи композиційні й художні особливості їх творів, студенти усвідомлюють органічну єдність народної й професійної творчості, відзначають як майстерно втілюється задум через композиційне й колористичне рішення.

У процесі виконання ескізів та довготривалих копіювання орнаментальних мотивів i композицій, копій розписів майстрів народного мистецтва та їх інтерпретацію у власних орнаментальних композиціях, майбутні вчителі образотворчого мистецтва прилучаються до традицій та духовної скарбниці національної та світової культури.

Для удосконалення практичних умінь та художнього досвіду студентам пропонуються завдання для індивідуальної роботи, що включають:

- замальовки характерних орнаментальних мотивів керамічного посуду, виробів з бронзи, шовкових тканин китайських майстрів; 
- копіювання мотивів японської лакової мініатюри, елементів розпису японського традиційного жіночого вбрання;

- ескізи орнаментів індійських ювелірних прикрас та розписів сарі;

- замальовки фрагментів арабського орнаменту;

- замальовки орнаменту архітектурних елементах готичної різьби з каменю;

- малюнки орнаментів епохи ренесансу;

- ескізи орнаментальних фрагментів декору бароко та рококо;

- вивчення мистецького доробку майстрів петриківського розпису.; замальовки розписів видатних художників Тетяни Пати, Федора Панка, Надії Білокінь;

- створення декоративних композицій на основі сучасних технік двоколірного мазка;

- розробка орнаментальних композицій для оздоблення сучасного одягу.

У процесі виконання практичних завдань, викладач зосереджує увагу студентів не тільки на копіювання i відтворення зразків відомих орнаментальних мотивів, але й пропонує на їх основі створювати нові декоративні мотиви й образи. Творчими завданнями можуть бути побудови орнаментальних композицій на основі стилізації геометричних, рослинних й тваринних форм. Студенти мають набути вмінь не просто копіювати зразки орнаментального народного мистецтва, а творчо інтерпретувати їх канони у власних композиціях.

\section{Висновки}

Підготовка майбутніх учителів-художників в системі вищої мистецької освіти вимагає досконалого вивчення специфіки та історії розвитку орнаментального мистецтва, художніх особливостей, композиційних засобів та символіки орнаменту. Оволодіння студентами видовими категоріями, художніми засобами, прийомами побудови й зображення орнаменту в різних художніх стилях і техніках сприяє підвищенню рівня їх фахової художньо-творчої компетентності за умови використання сучасної науково- 
обгрунтованої методики, що грунтується на психологічних, ціннісних та індивідуальних особливостях молоді.

\section{Література}

1. Антонович С. Захарчук-Чугай Р. Українське декоративне мистецтво : навч. посіб. Київ : Знання, 2012. 342 c.

2. Лозко Г. С. Етнологія України: Філософськотеоретичний та етнорелігієзнавчий аспект. Київ : АртЕк, 2004. 304 с.

3. Феномен нації: основи життєдіяльності / За ред. Б. В. Попова, В. О. Ігнатова, М. Т. Степико та ін. Київ : Знання, НАН України, Інститут філософії, 1998. 262 с.

4. Дряпіка В.І., Савченко Н. С. Розкриваючи естетичні цінності українського народного мистецтва: Книга для вчителя. Кіровоград : ТОВ «Імекс ЛТД», 2002. 151 с.

\section{Носаченко Т.Б.}

\section{Методологічні основи вивчення орнаменту у процесі професійної підготовки вчителів мистецтва}

\section{Анотація}

У статті розкривається сутність та значення декоративно-прикладного мистецтва в системі художньопедагогічної освіти, розкриваються методичні аспекти вивчення орнаменту, як засобу формування професійної майстерності майбутніх учителів образотворчого мистецтва. Доводиться актуальність і необхідність удосконалення методики вивчення орнаменту у процесі фахової підготовки студентів мистецького профілю. Орнамент розглядається як засіб розвитку у студентів професійних умінь, просторового мислення, формування авторського стилю та творчої індивідуальності.

Метою статті $є$ визначення шляхів ефективного впровадження у процес фахової підготовки майбутніх учителів образотворчого мистецтва сучасних технологій 
вивчення орнаменту, як засобу формування їх професійної компетентності.

Досліджуючи символічний зміст орнаментів встановлено, що студенти знайомляться з їх найпростішими архаїчними мотивами - лінією, колом, хрестом, ромбом, квадратом, крапкою, що має важливе значення для формування розуміння цілісності художнього твору, ставить за мету формувати відчуття композиційних законів побудови форми та декору й розвивати на цій основі художньо-творчі здібності.

Ключові слова: вчитель образотворчого мистецтва, студент, декоративно-прикладне мистецтво, народне мистецтво, професійна підготовка, професійна освіта, орнамент, символіка, професійні вміння, орнаментальна композиція.

\section{Носаченко Т.Б.}

\section{Методологические основы изучения орнамента в процессе профессиональной подготовки учителей искусства}

\section{Аннотация}

В статье раскрывается сущность и значение декоративно-прикладного искусства в системе художественно-педагогического образования, раскрываются методические аспекты изучения орнамента, как средства формирования профессионального мастерства будущих учителей изобразительного искусства. Доказывается актуальность и необходимость совершенствования методики изучения орнамента в процессе профессиональной подготовки студентов художественного профиля. Орнамент рассматривается как средство развития у студентов профессиональных умений, пространственного мышления, формирование авторского стиля и творческой индивидуальности.

Целью статьи является определение путей эффективного внедрения в процесс профессиональной 
подготовки будущих учителей изобразительного искусства современных технологий изучения орнамента, как средства формирования их профессиональной компетентности.

Исследуя символический смысл орнаментов, студенты знакомятся с их простыми архаичными мотивами - линией, кругом, крестом, ромбом, квадратом, точкой, имеет важное значение для формирования понимания целостности художественного произведения, ставит целью формировать ощущение композиционных законов построения формы и декора и развивать на этой основе художественно-творческие способности.

Ключевые слова: учитель изобразительного искусства, студент, декоративно-прикладное искусство, народное искусство, профессиональная подготовка, профессиональное образование, орнамент, символика, профессиональные умения, орнаментальная композиция. 